\title{
Growth suppression activity of bradykinin antagonists in glioma cells
}

\author{
S. S. Avdieiev', L. Gera², R. Hodges², Y. S. Vassetzky ${ }^{3}$, V. M. Kavsan ${ }^{1}$
}

\author{
${ }^{1}$ State Key Laboratory of Molecular and Cellular Biology \\ Institute of Molecular Biology and Genetics, NAS of Ukraine \\ 150, Akademika Zabolotnoho Str., Kyiv, Ukraine 03680 \\ ${ }^{2}$ University of Colorado Denver \\ Anschutz Medical Campus, Aurora CO 80045, USA \\ ${ }^{3}$ CNRS UMR8126, Paris-Sud University, Gustave Roussy Institute \\ 114 , rue Edouard Vaillant, 94805 Villejuif Cedex-France
}

\begin{abstract}
Conventional glioblastoma treatment still gives very modest results, thus development of the new treatment modalities is desperately needed for these disease. The present study was aimed at analyzing the effect of bradykinin (BK) antagonists on proliferation of the human glioblastoma cells U373. Methods. MTT-based cell proliferation assay. Results. BKM-570 revealed a significant antiproliferative activity in the U373 cells with $L C_{50} 3,8$ $\mu M$. Conclusions. The antiproliferative properties of BK antagonists were shown in vitro using the glioma cells. Further investigations of the molecular mechanisms of their action and pre-clinical studies on animal models are needed for the evaluation of these compounds as new anti-cancer drugs.
\end{abstract}

Keywords: bradykinin antagonists, glioma cells, antiproliferative activity.

Introduction. Glioblastoma is the most common and lethal form of the central nervous system tumors, and is known to be highly therapy resistant. Development of the new treatment modalities is desperately needed for these diseases.

Nonapeptide bradykinin (BK) is known to stimulate cancer cells growth [1] as well as their migration and invasion by inducing the activity of matrix metalloprotease (MMP) [2]. BK is linked to the formation of new blood vessels by stimulating the release of vascular endothelial growth factor (VEGF) [2]. These activities operate together to promote strongly the growth and invasive properties of certain tumor types, especially gliomas, thereby place BK in an ideal position for the generating of anti-cancer drugs.

The BK antagonists with impressive inhibition of the human cancer cell lines and the mouse tumor xenograt growth have been developed [3]. Despite the inten-

(C) Institute of Molecular Biology and Genetics, NAS of Ukraine, 2014 sive study of these compounds, there are no published data about their testing on the glioblastoma cell lines. Recently, it has been shown that BK acts through a bradykinin receptor 2 (B2R) as a chemoattractant guiding the glioma cells toward blood vessels in the rat brain slices [4].

Thus, B2R antagonist emerges as an attractive therapeutic agent for glioma patients.

It has been reported that anti-angiogenesis and antimatrix metalloproteases (MMP) activities are important components of the excellent in vivo anti-cancer activity of BK anatagonists. These substances offer advantages of combination therapy in one compound. These promising multitargeted anti-cancer compounds selectively stimulate apoptosis in cancers and also inhibit both angiogenesis and MMP action in treated lung and prostate tumors in nude mice.

Here we present that the BK antagonist BKM-570 possesses a high antiproliferative activity in the human glioblastoma cells U373. The obtained results demonst- 


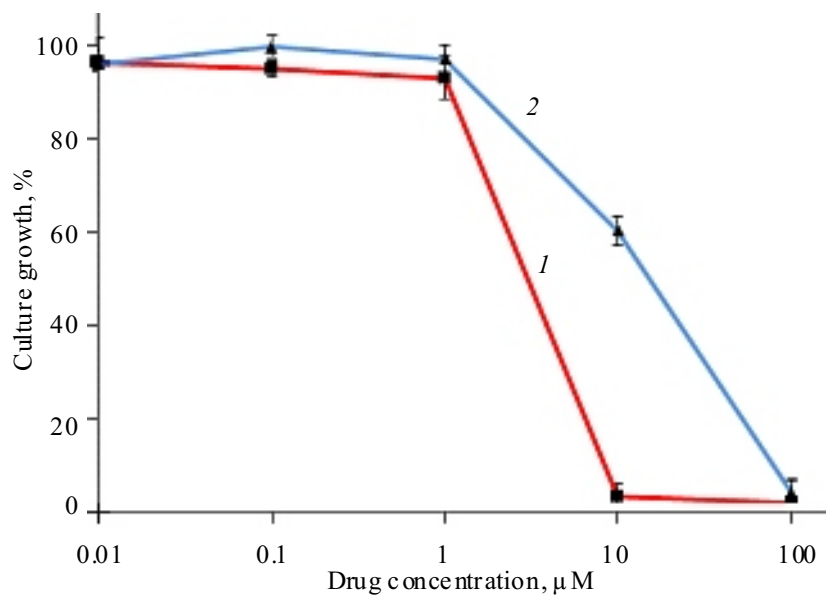

Effect of BK antagonists on U373 cells growth. U373 cells were cultured in the absence (vehicle control) or in the presence of increasing doses of BKM-570 (1) or BKM-1800 (2) for $72 \mathrm{~h}$. Cells viability was analyzed by MTT assay. Data are expressed as the percentage of growth compared to vehicle control (100\%). Each point represents the mean of three experiments performed in triplicate

rate that BKM-570 exhibits the anti-cancer activity. This work forms a basis for the pre-clinical studies using animal models for the evaluation of these compounds as new anti-cancer drugs.

Materials and methods. Cell proliferation assay. The U373 cells (obtained from R. E. Kavetskogo Institute of experimental pathology, oncology and radiobiology, NAS of UkraineU) were seeded in triplicates into 96 well plates at density $3 \cdot 10^{3}$ cells/well and were grown in complete DMEM («PAA», Germany) in an environment of $95 \%$ air $/ 5 \% \mathrm{CO}_{2}$.

The drugs were applied at final concentration of $0.01,0.1,1,10$, and $100 \mu \mathrm{M}$, which were reached by a serial dilution method. The cell proliferation was measured using 3-(4,5-dimethylthiazol-2-yl)-2,5- diphenyltetrazolium bromide (MTT) («Sigma», USA) after $72 \mathrm{~h}$ of cultivation.

Results and discussion. The cancer cells are characterized by an increased proliferation rate. To analyze the antiproliferative effect of the BK antagonists, we used the human glioblastoma cells U373. The MTT assay was employed to determine the growth-suppression effect of the tested compounds.

Based on the cytotoxicity test data, the $\mathrm{LC}_{50}$ parameter was calculated (molar concentration of compound leading to $50 \%$ cell death as compared to a control group treated with DMSO).
The non-peptide BK antagonist BKM-570 and its derivative BKM-1800 were enrolled in this study. It was found that BKM-570 revealed a significant growth suppressor activity in the U373 cells in dose-dependent manner after the addition to the culture medium (Figure, $A$ ). LC $_{50}$ of BKM-570 was $3,8 \mu \mathrm{M}$, while $\mathrm{LC}_{50}$ of BKM-1800 was $25,8 \mu \mathrm{M}$.

The obtained results were in accordance with those previously described by Stewart et al. [5]: BKM-570 was the leader compound both in vitro $\left(\mathrm{LC}_{50} 1,8 \mu \mathrm{M}\right.$ on the small-cell lung cancer (SCLC) cells) and in vivo (91 $\%$ inhibition of the tumor xenograf growth in mice). Our assays revealed much lower activity of BKM-1800, in contrast to the data published previously by Gera et al. $\left(\mathrm{LC}_{50} 1,7 \mu \mathrm{M}\right.$ on the SCLC cells in vitro and $78 \%$ of PC3 prostate cancer growth inhibition in vivo) [6].

Thus, the cytotoxic activity of these compounds seems to depend on the specificity of each cell line tested.

Conclusions. In summary, we have shown that BKM-570 represses the glioblastoma cells growth and is a promising compound for the in vivo studies as a potential anti-cancer agent.

Funding. This work was supported in part by State Agency for Science, Innovations and Informatization of Ukraine in frames of the project F33.4/001 «Identification of promising molecular biomarkers for monitoring of human neurodegenerative and oncological diseases» and the State Fund of Fundamental Research project F 46/366-2013.

\section{Антипроліферативна активність антагоністів}

брадикініну у клітинах гліоми

С. С. Авдеєв, Л. Гера, Р. Ходгес, Є. С. Васецький, В. М. Кавсан

Резюме

Стандартна терапія гліобластоми дає дуже незначні результати. Таким чином, розробка нових методів є вкрай необхідною для ефективного лікування цього захворювання. Мета представленого дослідження полягала в аналізі впливу антагоністів брадикініну на проліферацію клітин гліобластоми людини U373. Методи. МТТ аналіз пролиіферації клітин. Результати. ВКМ- 570 продемонстрував значну антипроліферативну активність у клітинах U373 ( $L C_{50} 3,8$ мкM). Висновки. Антипроліферативні властивості антагоністів брадикініну показано з використанням моделі гліоми in vitro. Подальші дослідження молекулярних механізмів діï, а також доклінічні випробування із застосуванням тваринних моделей необхідні для оцінювання зазначених сполук як нових протиракових препаратів. 
Ключові слова: антагоністи брадикініну, клітини гліоми, антипроліферативна активність.

Антипролиферативная активность антагонистов брадикинина в клетках глиомы

С. С. Авдеев, Л. Гера, Р. Ходгес, Е. С. Васецкий, В. М. Кавсан

Резюме

Стандартная терапия глиобластомы дает очень незначительные результаты. Таким образом, разработка новых методов крайне необходима для эффективного лечения этого заболевания. Цель данного исследования состояла в анализе влияния антагонистов брадикинина на пролиферацию клеток глиобластомы человека U373. Методы. МТТ анализ пролиферации клеток. Результаты. ВКМ-570 продемонстрировал значительную антипролиферативную активность в клетках U373 (LC $C_{50} 3,8$ мкM). Выводы. Антипролиферативные свойства антагонистов брадикинина показаны с использованием модели глиомы in vitro. Дальнейшие исследования молекулярных механизмов действия, а также доклинические испытания с применением животных моделей необходимы для оиенки этих соединений в качестве новых противораковых препаратов.

Ключевые слова: антагонисты брадикинина, клетки глиомы, антипролиферативная активность.

\section{REFERENCES}

1. Wu J, Akaike T, Hayashida K, Okamoto T, Okuyama A, Maeda $H$. Enhanced vascular permeability in solid tumors involving peroxynitrite and matrix metalloproteases. Jpn J Cancer Res. 2001; 92(4):439-51.

2. Wu J, Akaike T, Maeda H. Modulation of enhanced vascular permeability in tumors by a bradykinin antagonist, a cyclooxygenase inhibitor and a nitric oxide scavenger. Cancer Res. 1998; 58 (1):159-65.

3. Gera L, Chan DC, Helfrich B, Bunn PA, York EJ, Stewart JM. Bradykinin-related compounds having anticancer activity in vivo superior to cisplatin and SU5416. Peptides 2000. Proc. of the $26^{\text {th }}$ Eur. Peptide Symp. Eds J. Martinez, J.-A. Fehrentz. Paris: EDK Publ., 2001; 637-8.

4. Montana $V$, Sontheimer $H$. Bradykinin promotes the chemotactic invasion of primary brain tumors. J Neurosci. 2011; 31(13): 4858-67.

5. Stewart JM, Gera L, Chan DC, Bunn PA, York EJ, Simkeviciene $V$, Helfrich $B$. Bradykinin-related compounds as new drugs for cancer and inflammation. Can J Physiol Pharmacol. 2002; 80 (2):275-80.

6. Gera L, Chan DC, Simkeviciene V, Bunn PA, Stewart JM. N(Fluorenyl-9-methoxycarbonyl)amino acid amide derivatives as a newclass of anti-cancer agents. Adv Exp Med Biol. 2009; 611: 465-6.

7. Myers MP, Pass I, Batty IH, Van der Kaay J, Stolarov JP, Hemmings BA, Wiggler MH, Downes CP, Tonks NK. The lipid phosphatase activity of PTEN is critical for its tumorsupressor function. Proc Natl Acad Sci USA. 1998; 95(23):13513-8.

Received 15.07.13 